\title{
RETURNING TO WRAY: SOME RECENT CASES ON SECTION 24 OF THE CHARTER*
}

BRUCE P. ELMAN**

\section{INTRODUCTION: THE WRAY CASE}

Prior to the advent of the Canadian Charter of Rights and Freedoms, ${ }^{1}$ the evidentiary landscape was dominated by the case of $R$. v. Wray. ${ }^{2}$ The facts of the Wray case are well known to all. In this case, the Crown tendered certain pieces of evidence obtained as a result of an involuntary confession. The trial Judge excluded this evidence and the Ontario Court of Appeal upheld the trial Judge's ruling. In an oral judgment, Justice Aylesworth stated: ${ }^{3}$
In our view, a trial Judge has a discretion to reject evidence, even of substantial weight, if he considers that its admission would be unjust or unfair to the accused or calculated to bring the administration of justice into disrepute, the exercise of such discretion, of course, to depend upon the particular facts before him. Cases where to admit certain evidence would be calculated to bring the administration of justice into disrepute will be rare, but we think the discretion of a trial Judge extends to such cases.

However, upon further appeal to the Supreme Court of Canada, this ruling was reversed and a new trial ordered. The Supreme Court held that there was no discretion in the trial Judge to exclude otherwise admissible evidence on the basis that it was obtained by illegal or improper means or in a manner tending to bring the administration of justice into disrepute. Justice Martland, writing for the majority, stated: ${ }^{4}$

[T] he exercise of a discretion by the trial judge arises only if the admission of the evidence would operate unfairly. The allowance of admissible evidence relevant to the issue before the court and of substantial probative value may operate unfortunately for the accused, but not unfairly. It is only the allowance of evidence gravely prejudicial to the accused, the admissibility of which is tenuous, and whose probative force in relation to the main issue before the court is trifling, which can be said to operate unfairly.

Consequently, it is obvious that the method of obtaining evidence played no part in the determination of when a trial Judge should exercise his discretion to exclude otherwise admissible evidence. Thus, the Wray case stands for the proposition that evidence which is relevant is admissible no matter how it is obtained unless, of course, its use violates one of the wellrecognized rules of exclusion in the law of evidence.

- In some respects this comment is a sequel to Elman, "Collins v. The Queen: Further Jurisprudence on Section 24(2) of the Charter" (1987) 25 Alta. L. Rev. 477.

** Of the Faculty of Law at the University of Alberta, Edmonton.

1. Constitution Act, 1982, hereinafter referred to as the Charter.

2. [1971] S.C.R. 272, [1970] 4 C.C.C. 1, revg. [1970] 3 C.C.C. 122 (Ont. C.A.).

3. Id. at 123 of [1970] 3 C.C.C.

4. Id. at 293 of [1971] S.C.R. 
The Wray decision was applied to the Canadian Bill of Rights ${ }^{5}$ in the case of Hogan v. The Queen. ${ }^{6}$ In this case, the accused had been taken to the police station for breathalyser testing. He requested the right to speak to his lawyer prior to taking the test. The officer in charge refused to allow the accused to speak to his counsel, even though the lawyer was present in an adjoining room. The police officer demanded that the accused blow into the breathalyser or face a charge of failing or refusing to provide a sample of one's breath for the purpose of analysis. Faced with this alternative, the accused complied and registered a reading of $230 \mathrm{mg}$. of alcohol per 100 $\mathrm{ml}$. of blood. Hogan was charged, therefore, with violating section 236(1) of the Criminal Code, i.e., driving a motor vehicle having consumed alcohol in a quantity such that the proportion of alcohol in his blood exceeded $80 \mathrm{mg}$. per $100 \mathrm{ml}$. of blood. He was convicted of the offence and his appeal to the Appeal Division of the Supreme Court of Nova Scotia was denied. His further appeal to the Supreme Court of Canada was based on the following proposition: Having been denied his right to counsel pursuant to section 2(c)(ii) of the Canadian Bill of Rights, his conviction for violation of section 236(1) of the Criminal Code should be quashed.' A majority of the Supreme Court rejected this proposition. Justice Ritchie delivered the judgment of the majority: ${ }^{8}$

[W] hatever view may be taken of the constitutional impact of the Bill of Rights, and with all respect for those who may have a different opinion, I cannot agree that, wherever there has been a breach of one of the provisions of that Bill, it justifies the adoption of the rule of "absolute exclusion" on the American model which is in derogation of a common rule long accepted in this country.

Justice Laskin took the opposite view in his dissenting reasons: ${ }^{9}$

The Canadian Bill of Rights is a half-way house between a purely common law regime and a constitutional one; it may aptly be described as a quasi-constitutional instrument. It does not embody any sanctions for the enforcement of its terms, but it must be the function of the Courts to provide them in light of the judicial view of the impact of that enactment. ... It is to me entirely consistent, and appropriate, that the prosecution in the present case should not be permitted to invoke the special evidentiary provisions of $\mathbf{s . 2 3 7}$ of the Criminal Code when they have been resorted to after denial of access to counsel in violation of s. 2(c)(ii) of the Canadian Bill of Rights. There being no doubt as to such denial and violation, the Courts must apply a sanction. We would not be justified in simply ignoring the breach of a declared fundamental right or in letting it go merely with words of reprobation. Moreover, so far as denial of access to counsel is concerned, I see no practical alternative to a rule of exclusion if any serious view at all is to be taken, as I think it should be, of this breach of the Canadian Bill of Rights.

Thus, the case of $R$. v. Wray established the proposition that evidence which is relevent is admissible, no matter how it is obtained. This principle established in Canada, at least until the advent of the Charter, an unshakeable rule of absolute admission of evidence.

5. Canadian Bill of Rights, S.C. 1960, c. 44.

6. [1975] 2 S.C.R. 574, (1975) 48 D.L.R. (3d) 427, 18 C.C.C. (2d) 65.

7. Hogan found some support for his position in Brownridge v. The Queen [1972] S.C.R. 926, 7 C.C.C. (2d) 417. In this case, the phrase "without reasonable excuse" in s. 235(2) of the Criminal Code was interpreted so as to be consistent with the Canadian Bill of Rights. Consequently, the denial of Brownridge's right to counsel provided him with a "reasonable excuse" for failing or refusing to provide a breath sample and resulted in an acquittal. Hogan, quite naturally, assumed that the conviction of the accused should not depend upon whether the accused blew or not when the denial of right to counsel was the same.

8. Supra n. 6 at 584 of [1975] 2 S.C.R.

9. Id. at 597-598. 
[VOL. XXVI, NO. 3

\section{CRITICISM OF WRAY: MOVING TOWARDS THE CHARTER}

$R$. v. Wray attracted much attention and considerable criticism. ${ }^{10}$ Even prior to the Wray decision, the Ouimet Committee, in 1969, favored a discretion in the trial Judge to exclude evidence which was illegally obtained." The Law Reform Commission of Canada, in its Proposed Evidence Code, included the following provisions: ${ }^{12}$

Evidence shall be excluded if it was obtained under such circumstances that its use in the proceedings would tend to bring the administration of justice into disrepute.

In attempting to counteract the restrictiveness of the Wray decision, the Commission suggested guidelines for the exercise of this discretion. These guidelines were stated as follows: ${ }^{13}$

In determining whether evidence should be excluded under this section, all the circumstances surrounding the proceedings and the manner in which the evidence was obtained shall be considered, including the extent to which human dignity and social values were breached in obtaining the evidence, the seriousness of the case, the importance of the evidence, whether any harm to an accused or others were inflicted willfully or not, and whether there were circumstances justifying the action, such as a situation of urgency requiring action to prevent destruction or loss of evidence.

The principle at the core of these provisions was echoed by the Ontario Law Reform Commission in its report in 1976. The Commission saw the need to give power to the Court to refuse to admit evidence obtained by illegal means. The Commission pointed out the importance of maintaining the integrity of the judicial process by ensuring the fair administration of justice. After an exhaustive discussion of the Wray decision, the Commission concluded: 14

In our view, the principles relied on in the dissenting judgments of the Supreme Court of Canada and in the judgment of the Court of Appeal should be used as a guide for remedial legislation.... We think trial judges should have control over the admission of evidence so as to preserve the integrity of the judicial process and protect the administration of justice from practices likely to bring it into disrepute. The judicial process is not confined to the courts; it also encompasses officers of the law and others whose duties are necessary to ensure that the courts function effectively.

Finally, the MacDonald Royal Commission Report, entitled Freedom and Security Under the Law, also recommended a statutory judicial discretion to exclude illegally obtained evidence. ${ }^{15}$

The Wray decision and its offspring were also the subject of considerable discussion before the Special Joint Committee on the Constitution of

10. See, for example, Weinberg, "The Judicial Discretion to Exclude Relevant Evidence" (1975) 21 McGill L. J. 1; Gibson, "Illegally Obtained Evidence" (1973) U. of T. Fac. L.R. 23; Sheppard, "Restricting the Discretion to Exclude Admissible Evidence" (1972) 14 Crim. L. Q. 334; Heydon, "Illegally Obtained Evidence" [1973] Crim. L. R. 603, 690.

11. Report of the Committee on Corrections (Ouimet Committee Report) (1969) at 74.

12. Law Reform Commission of Canada, Report on Evidence (1975) at 22.

13. Id. We should note that the Law Reform Commission's proposals were influenced by the law in other Commonwealth countries. See, for example, the Scottish case of Lawrie v. Muir [1950] S.L.T. 37 at 39-40, the Australian case of $R$. v. Ireland (1970) 126 C.L.R. 321 at 334-5, the New Zealand cases of Police v. Hall [1976] 2 N.Z.L.R. 678 at 684 and R. v. Pethig [1977] 1 N.Z.L.R. 448 at 453, the Irish cases of People v. O'Brien [1965] I.R. 142 at 160 and People v. O'Laughlin [1979] I.R. 85 at 92.

14. Ontario Law Reform Commission, Report on the Law of Evidence (1976) at 94.

15. Freedom and Security Under the Law (The Second Report) at 1045. It should be noted that the opposite opinion was expressed by the Federal/Provincial Task Force on the Uniform Rules of Evidence (1982) at 233. 
Canada. In testimony before the Special Joint Committee, civil liberties groups stressed the need for a strong enforcement provision to be included in the Charter. ${ }^{16}$

These groups pointed out that the Canadian Bill of Rights was notable because of the absence of an enforcement section. This had resulted in the Supreme Court of Canada taking the position that their remedial powers were limited to declaring challenged legislation inoperative to the extent of any inconsistency with the Bill of Rights. Thus, remedies such as the exclusion of evidence, were not granted by the Supreme Court of Canada when a Bill of Rights violation occurred. ${ }^{17}$

In the Proposed Joint Resolution, section 26 had the effect of preserving the principles developed by the Supreme Court in $R$. v. Wray. Professor Tarnopolsky in discussing section 26 , stated: ${ }^{18}$

[W] hat the Supreme Court then said was that they could not find in the Canadian Bill of Rights a reason to override the long standing rule of evidence, that evidence if obtained even illegally is admissible if relevant. Now, that, Mr. Chairman, we suggest is exactly what 5.26 enshrines. Section 26 enshrines the rule that evidence, even if illegally obtained, is admissible if relevant and I cannot imagine a Bill of Rights that we would want to hold up proudly in the world having that kind of provision specifically protected.

In light of responses of this sort, the then Minister of Justice, Jean Chretien, agreed to delete section 26 dealing with the admissibility of evidence. After submissions by members of the Opposition, further revisions were made. These revisions ultimately resulted in the present section 24(2). This section gives the courts specific direction to exclude evidence in certain circumstances, thereby implicitly overruling, at least in part, the majority decision of the Supreme Court of Canada in R. v. Wray.

Thus, section 24(2) represents a balancing of interests or values - it was a compromise between the "Absolute Rule of Admission", as exemplified in Wray and an "Absolute Rule of Exclusion", as seen in the American jurisprudence of the time. It was, further and more importantly, the product of the political process of the time.

\section{THE CASE OF COLLINS v. THE QUEEN}

It may be convenient at this point to restate the contents of section 24 of the Charter. Section 24 provides:

(1) Anyone whose rights or freedoms, as guaranteed by this Charter, have been infringed or denied may apply to a Court of competent jurisdiction to obtain such remedy as the Court considers appropriate and just in the circumstances.

(2) Where in proceedings under subsection (1), a Court concludes that evidence was obtained in a manner that infringed or denied any rights or freedoms guaranteed by this Charter, the evidence shall be excluded if it is established that, having regard to all the circumstances, the admission of it in the proceedings would bring the administration of justice into disrepute.

16. For a fuller discussion of the history of section 24 of the Charter, see McLellan and Elman, "The Enforcement of the Canadian Charter of Rights and Freedoms: An Analysis of Section 24" (1983) 21 Alta. L. Rev. 205.

17. Special Joint Committee on the Constitution of Canada, Proceedings, 32nd Parl., Sess. 1 (1980-81), No. 7 at 15 . (The Testimony of Professor Walter Tarnopolsky).

18. Id. 
The case of Collins v. The Queen ${ }^{19}$ represents the Supreme Court's most profound statement on section 24(2) of the Charter. Although other cases ${ }^{20}$ involving section 24(2) preceded Collins, the latter case represents the first, and to date, the most extensive statement on the interpretation of the subsection.

Ruby Collins was charged with possession of heroin for the purpose of trafficking. The heroin was found in a balloon in Ruby's hand at the same time as a chokehold was being applied, with considerable force, to her throat by an R.C.M.P. constable.

At trial, County Court Judge Wong held that the search was unlawful and unreasonable and, therefore, a contravention of section 8 of the Charter. However, relying on the judgment of the Supreme Court of Canada in Rothman v. The Queen, ${ }^{21}$ Judge Wong held that the defendant had failed to satisfy him that the evidence should be excluded pursuant to section 24(2) of the Charter.

\section{Judge Wong stated: ${ }^{2}$}

Turning now to the case at bar, would any ordinary, right-thinking person think that seizing and searching a suspected hard drug trafficker for possession of illicit drugs be shocking to the community? The answer is self-evident. ... I have concluded that, having regard to all the circumstances of this case, police conduct here is not shocking such that the admission of the evidence... would necessarily cast the administration of justice into disrepute. Accordingly, the evidence will be admitted. [Emphasis added]

The evidence was admitted and Ruby Collins was found guilty. Ruby Collins' appeal to the British Columbia Court of Appeal was unanimously dismissed. In doing so, the Court endorsed the reasoning of the trial Judge.

Subsequently, Ruby Collins appealed to the Supreme Court of Canada. The Supreme Court granted the appeal but ordered a new trial. ${ }^{23}$

In writing for a majority of the Court, Justice Lamer considered the following question: ${ }^{24}$

... having regard to all the circumstances, would the admission of the evidence bring the administration of justice into disrepute?

In a brief discussion of the social policy underlying section $24(2)$ of the Charter, Justice Lamer noted that the focus of the inquiry is on the point in

19. [1987] 1 S.C.R. 265.

20. See, for example, $R$. v. Therens (1985) 45 C.R. (3d) 97, Rahn v. The Queen (1985) 45 C.R. (3d) 134, Trask v. The Queen (1985) 45 C.R. (3d) 137, Clarkson v. The Queen [1986] 1 S.C.R. 383.

21. [1981] 1 S.C.R. 640 .

22. Cited by Seaton J.A. in Collins v. The Queen (1983) 5 C.C.C. (3d) 141 at 149.

23. A curious problem arose in the trial of Ruby Collins. Crown counsel was attempting to show the reasonable basis for the constable's belief that a narcotic was present, when defence counsel objected to the line of questioning on the grounds that it would elicit hearsay testimony. It is unclear from the record whether the trial Judge upheld the objection or simply failed to rule on it. In any event, Crown counsel halted the line of questioning and, consequently, failed to establish the reasonableness of the constable's belief. Taking the evidence as provided, the search was found to be unreasonable. Because the defence counsel's objection was unfounded, the Supreme Court decided that the matter should be sent back for a new trial.

24. Supra n. 19 at 277. 
the process where the Crown seeks to have the unconstitutionally obtained evidence admitted at the trial. Thus, it follows that the focus of the inquiry is not on the conduct of the police officers. His Lordship stated:25

Misconduct by the police in the investigatory process often has some effect on the repute of the administration of justice, but section 24(2) is not a remedy for police misconduct, requiring the exclusion of the evidence if, because of this misconduct, the administration of justice was brought into disrepute. ... the purpose of section 24(2) is to prevent having the administration of justice brought into further disrepute by the admission of the evidence in the proceedings. [Emphasis added]

Justice Lamer noted, further, that any disrepute that may arise from the exclusion of evidence should also be considered. To determine disrepute, Justice Lamer adopted the test proposed by Professor Morrisette: ${ }^{26}$

Would the admission of the evidence bring the administration of justice into disrepute in the eyes of the reasonable man, dispassionate and fully apprised of the circumstances of the case?

To this Justice Lamer added:27

The reasonable person is usually the average person in the community, but only when that community's current mood is reasonable.

Consequently, according to Justice Lamer, the decision of whether to exclude unconstitutionally obtained evidence is not left to the "untramelled discretion" of the trial Judge.

The Charter directs the court to consider "all the circumstances" in determining whether the admission of the evidence would bring the administration of justice into disrepute. According to Justice Lamer, the following factors are to be considered:

\section{Fairness of the Trial}

If the admission of the evidence will affect the fairness of the trial, then admitting the evidence in the proceeding would tend to bring the administration of justice into disrepute. In this context, Justice Lamer drew a distinction between real evidence - evidence that existed irrespective of the Charter violation - and self-incriminatory evidence - that which may have been created out of a breach of the Charter right..$^{28}$

\section{Seriousness of the Charter Violation}

This inquiry focuses on the disrepute which will result from the apparent judicial condonation of police misconduct by the acceptance of the evidence. Justice Lamer noted that the failure to proceed in a constitutionally proper manner, when that option is available, tends to indicate a blatant disregard for the Charter. Such a disregard for the Charter would generally result in excluding the evidence. ${ }^{29}$

25. Id. at 280-281.

26. Id. at 282. This test is provided by Professor Morrisette in "The Exclusion of Evidence under the Canadian Charter of Rights and Freedoms: What to Do and What Not to Do" (1984) 29 MCGill L.J. 521 at 538.

27. Id.

28. Id. at 284. This distinction between real evidence and self-incriminatory evidence takes on great significance in the more recent cases.

29. Id. at 285. 


\section{Effect of Exclusion}

Finally, it is necessary to consider disrepute that may arise from the exclusion of the evidence. In this context the seriousness of the offence will be considered..$^{30}$

Applying the foregoing law to the facts, Justice Lamer held that, although the evidence was real evidence, and although there is nothing to suggest that the admission of the evidence would create an unfair trial and in spite of the fact that the cost of excluding the evidence is relatively high, the evidence must be excluded because of the flagrant violation of the rights of the accused due to the misconduct of the police. He stated that the Court must "dissociate [sic] itself from the conduct of the police in this case". ${ }^{31}$

\section{WHAT THE COLLINS CASE DOESN'T SAY}

Although Collins is important for what it says about section 24(2), it is equally important for what it doesn't say. In particular, the Supreme Court of Canada provides no guidance on two important issues: (1) Causation and (2) Good faith.

\section{Causation: The Relationship Between the Violation and the Evidence}

Section 24(2) requires that the evidence must have been "obtained in a manner that infringed" the Charter. This implies that there must be some connection between the violation of the Charter right and the obtaining of the evidence. The extent of this relationship was the subject of discussion in the earliest exclusion case, $R$. v. Therens.$^{32}$ In this case the question arose whether the results of a breathalyser test should be excluded because the accused had been denied his right to retain and instruct counsel without delay and the right to be informed of such right. In the Supreme Court the Justices took the opportunity to comment on the above noted words. Justice Le Dain, with whom Justice McIntyre concurred, stated: ${ }^{33}$

The first requirement suggests that there must be some connection or relationship between the infringement or denial of the right or freedom in question and the obtaining of the evidence the exclusion of which is sought by the application. Some ccurts have held, or appeared to have assumed, that the relationship must be one of causaticn, similar to the "but for" causation requirement of tort law.

Justice Le Dain then referred to the French version of section 24(2) wherein the following words are used: "obtenus dans des conditions qui portent atteinte aux droits ou libertés garantis par la présente charte". Justice Le Dain noted that these words: $:^{34}$

.. do not connote or require a relationship of causation. It is sufficient if the infringement or denial of the right or freedom has preceded or occured in the sourse of, the obtaining of the evidence. It is not necessary to establish that the evidence 'would not have been obtained but for the violation of the Charter.

30. Id. at 285-286.

31. Id. at 288. Justice Le Dain concurred in result although not in all propositions advanced by Justice Lamer. Justice McIntyre dissented on the issue of the exclusion of the evidence.

32. Supra n. 20.

33. Id. at 129.

34. Id. at 130. 
Justice Lamer, with whom the Chief Justice concurred, did not agree entirely with the formulation proposed by Justice Le Dain. Justice Lamer stated: ${ }^{35}$

However, in order to meet the requirements for exclusion of evidence under s. 24(2) there must not only exist a violation of a Charter right, but there must also be, as was said by Le Dain J., "some connection or relationship between the infringement or denial of the right or freedom in question and the obtaining of the evidence the exclusion which is sought by the application".

With respect, however, I cannot subscribe to the proposition later advanced by Le Dain J. that this requirement is met by the simple fact that the infringement or denial of the right has preceded the obtaining of the evidence. Indeed, if there is no relationship other than a temporal one, the evidence was not "obtained in a manner that infringed" the Charter.

The causation issue arose once again in the case of $R$. v. Manninen ${ }^{36}$ In this case the Respondent was arrested for theft, possession of a stolen car, and armed robbery. The arresting officer twice read the Respondent his rights from a card, the second reading being due to a flippant remark made by the Respondent following the first reading. The Respondent then indicated that he was not going to say anything until he saw his lawyer. Nevertheless, the officers continued to question him. The Respondent did not directly request the use of a telephone. The officers did not offer it. The Respondent only spoke to his lawyer when his lawyer called upon him later at the police station.

In convicting the accused, the trial Judge relied on a statement made as part of the following exchange between the officers and the accused: ${ }^{37}$
Q. What is your full name?
A. Ronald Charles Manninen.
Q. Where is your address?
A. Ain't got one. Q. Where is the knife that you had along with this (showing the Respondent the $\mathrm{CO}_{2}$
gun found in the car) when you ripped off the Mac's Milk on Wilson Avenue?
A. He's lying. When I was in the store I only had the gun. The knife was in the tool box in the car.

The trial Judge convicted the accused. He further held that even if the right to counsel had been infringed, the admission of the statements would not bring the administration of justice into disrepute. The Court of Appeal unanimously allowed the Respondent's appeal, quashing the convictions and ordering a new trial.

The Supreme Court of Canada dismissed the appeal. In a short statement on the issue of causation the Supreme Court of Canada noted: ${ }^{38}$

There must thus be some relationship or connection between the violation and the evidence. In my view, a sufficient relationship or connection is obviously made out where, as in this case, the evidence was obtained as a direct consequence of the violation of the Charter.... It is not necessary to define with any greater precision the nature of the relationship or connection required.

35. Id. at 109.

36. [1987] 1 S.C.R. 1233.

37. Id. at 1238 .

38. Id. at 1244-45. 
The question, as to exactly what type of relationship is required between the Charter violation and the evidence, is an important one. One can see that in a case such as $R$. v. Cutforth, ${ }^{39}$ the causation issue is clear. In this case the accused was arrested for impaired driving and driving over .08 . The accused was kept in custody for approximately twelve hours, five hours longer than he should have been. This detention, determined by the trial Judge to be arbitrary and a violation of section 9 of the Charter, took place after all of the evidence regarding the impairment and the blood alcohol level had been obtained. The trial Judge, therefore, held, quite rightly in my view, that the evidence of impairment and the Certificate of Analysis were admissible as they had not been obtained in a manner that infringed any Charter right..$^{40}$ However, a case such as $R$. v. Brydges, ${ }^{41}$ provides a much different example. In this case the Defendant was arrested in December of 1985 at Strathclair, Manitoba, for a 1979 murder in Edmonton, Alberta. At the time of his arrest, Brydges was read the standard police warning. At that time, he indicated that he understood the nature of the caution. Subsequently, he was taken to Brandon where he was interviewed by the arresting officer, Detective Harris of the Edmonton City Police Department. Their interview was recorded. The following exchange took place: ${ }^{42}$

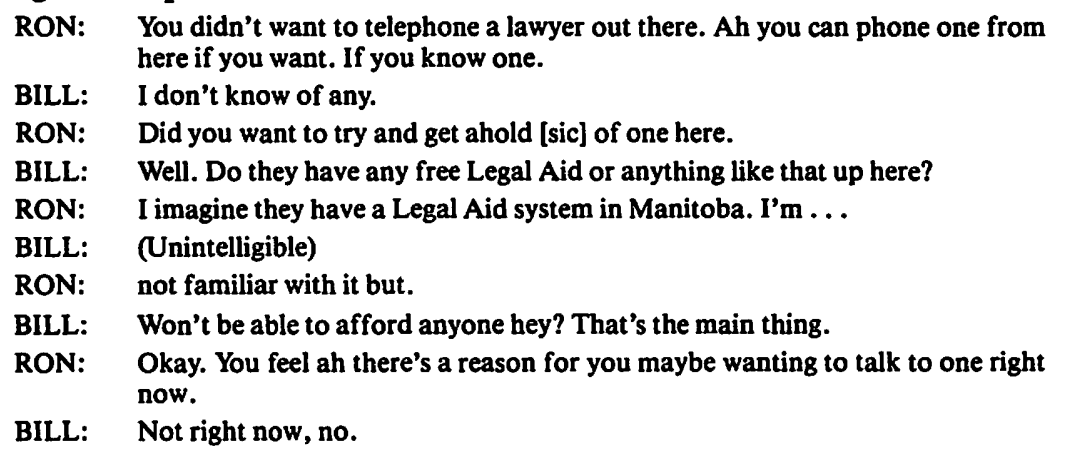

Subsequently, the accused gave an inculpatory statement. Based on this conversation, however, Justice Wachowich found that the accused's right to counsel had been infringed. Justice Wachowich held that the accused's response to the police officer's question as to whether he wanted to retain counsel, was "equivocal" as it related to the inability to afford counsel. His Lordship, further, held that the accused had not been given the assistance needed to exercise his right to counsel. He also held that this right had been denied because there was no clear waiver of this right as required by the Supreme Court of Canada decision in Clarkson v. The Queen.$^{43}$ In conclusion, Justice Wachowich held that the evidence should be excluded pursuant to section 24(2) of the Charter. The Alberta Court of

39. (1988) 55 Alta. L.R. (2d) 193 (Alta. C.A.).

40. Id. at 200. Precisely what remedy would be appropriate is discussed in Ziff and Elman, "Case Comment: Devaluing Due Process Values: R. v. Cutforth" (1988) 55 Alta. L.R. (2d) 207.

41. (1988) 55 Alta. L.R. (2d) 330 (Alta. C.A.).

42. Id. at 333. "Ron" is Detective Harris and "Bill" is the defendant Mr. Br./dges.

43. Supra n. 20. 
Appeal, by a majority of two to one, overturned Justice Wachowich's decision. Justice McClung held, Justice Haddad concurring, that there had been no infringement of the accused's right to counsel. Even if there had been an infringement the Court went on to say, there was no causal connection between the obtaining of the statement and the breach of the right. ${ }^{44}$

It is difficult to understand the majority's view that there was no causal connection between the violation of the right and the obtaining of the evidence. It would appear that the Supreme Court of Canada does not require that the accused satisfy a "but for" test in order to show that the evidence was obtained "in a matter that infringed a Charter right". This much seems clear from the judgments in Therens. ${ }^{45}$ Furthermore, the decisions of the Supreme Court of Canada in Clarkson, ${ }^{46}$ and Manninen ${ }^{47}$ are difficult to distinguish from the Brydges case.

The decision seems to run counter to some Court of Appeal decisions as well. In $R$. v. Strachan, Justice Esson distills the Therens decision into three principles. In regard to the issue of causation, his Lordship stated the following: ${ }^{48}$

The first test in s. 24(2) (evidence obtained in a manner which violates a Charter right) does not limit the application of the section to evidence obtained as a result of the violation. The section may apply notwithstanding the absence of a strict causal relationship. Such absence, however, is a most important consideration in deciding whether the second test, that as to whether the admission of the evidence would bring the administration of justice into disrepute, has been met.

In Laplante v. The Queen, Justice Vancise discussed the phrase, "obtained in a manner that infringed or denied a right" as follows: ${ }^{49}$

The word "manner" does not equate to "by a violation of" or "by reason of an infringement". It is a more flexible concept. The New International Dictionary defines "manner" as: "the mode or method in which something is done or happens; a mode of procedure or way of acting". The Concise Oxford Dictionary defines it as: "Way a thing is done or happens". The expression "in a manner", does not connote a direct or exact causal connection between the act and the denial or infringement of the right. The violation must relate to the infringement that accounts for, or was the reason for, the impugned evidence being obtained. It follows that the infringement must precede the obtaining of the evidence. The French version "obtenus dans des conditions" reinforces the interpretation that there need not be an exacting causal connection. In my opinion, there is a sufficient connection where the evidence was obtained as a direct result of the Charter violation.

The relationship between the Charter violation and the obtaining of the evidence which existed in the Brydges case would seem to fall squarely within the parameters suggested by Justice Vancise in the Laplante case.

44. Supra n. 41 at 334. McClung J.A. stated: “.. . exclusion can only follow from the conclusion that the traduction of the right produced the challenged evidence. This was not established." [Emphasis added].

45. Supra n. 20. See also supra notes $33,34,35$ and accompanying text.

46. Supra n. 20.

47. Supra n. 36.

48. (1986) 49 C.R. (3d) 289 at 298.

49. (1987) 59 S.R. 251 at 261. 
Two further points need to be made regarding this issue. Nothing in the wording of section 24(2) limits the scope of its operation to primary evidence only. Indeed, the section would appear to apply to derivative evidence as well. ${ }^{\text {so }}$

That section 24(2) has application to such evidence is a reasonable interpretation of the words contained in the section. It should be noted, however, that as the relationship between the obtaining of the evidence and the violation of the Charter becomes more tenuous, there is a greater likelihood that courts will rule either that the evidence was not "obtained in a manner that infringed or denied any rights" or that the admission of the evidence would not "bring the administration of justice into disrepute". In regard to derivative evidence, Justice Le Dain said the following in Therens::

I recognize, however, that in the case of derivative evidence, which is not what is in issue here, some consideration may have to be given in particular cases to the question of relative remoteness.

Some recent Court of Appeal cases seem to have put a new light on this issue, however. In the case of $R$. v. Woolley, secondary or derivative evidence obtained as a result of an unconstitutional statement was held to be admissible. The police officers were investigating the accused as the possible suspect in the theft of a 1986 Chevrolet Corvette, valued at $\$ 41,800.00$. In this case the following exchange took place between police officers and the accused: ${ }^{32}$

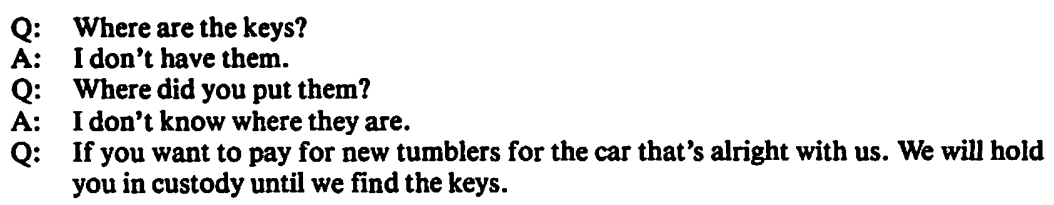

In this case, the Ontario Court of Appeal held that section 7 of the Charter included a right to remain silent. They further concluded that any utterances which may have been made by the Defendant following the above exchange would not have been found to have been made voluntarily. Subsequent to this exchange, Woolley directed the police officers to a farm where the Corvette had been found abandoned. Upon arrival at the farm, the police officers followed the driveway up to the building where the accused told them to stop. He got out of the police cruiser, walked to the other side of a snowbank, reached down into the snowbank, and pulled out the original set of keys to the stolen Corvette, handing them to the police officer. The trial Judge excluded this evidence. The Court of Appeal reversed this decision, allowed the appeal and directed a new trial. In the

50. In the United States, this doctrine is known as "the fruit of the poison tree" doctrine. The rule is as follows:

Evidence derived from information acquired by police officials through unlawful means is not admissible in the criminal prosecution.

51. Supran. 20 at 130.

52. (1988) 25 O.A.C. 390 at 393. 
course of his judgment in this case, Justice Cory seems to apply some sort of "shock the community test", a test which was disapproved of in Collins..$^{33}$ Justice Cory stated: ${ }^{54}$

As well, the American authorities support this position. In the United States, the admission of evidence that was obtained contrary to the due process provisions of the American Constitution is dependent [sic] upon the application of the test as to whether or not the admission of such evidence would shock the conscience. The United States Supreme Court has held that convictions obtained by methods that "shock the conscience" must fall. ... Here, the admission of the evidence which might well lead to a conviction would not "shock the conscience". [Emphasis added]

An added twist to this issue must be mentioned. You may recall that in the Collins case, Justice Lamer seemed to draw some distinction between real evidence - evidence that existed irrespective of the Charter violation - and self-incriminatory evidence - that which may have been created out of the breach of the Charter right. ${ }^{.5}$ Out of this dictum (for it should be remembered that Collins involved a case of real evidence), various Courts of Appeal have seemingly suggested that real evidence, pre-existing the Charter violation, could never be obtained in a manner which infringed or denied Charter rights. The Woolley case is one example of this. In support of his decision to admit the evidence of the keys, Justice Cory stated:56

In the case at bar, the admission of the evidence would not effect the fairness of the trial.

The production of the keys constituted real or physical evidence that persuasively

established the guilt of the respondent, the only person who knew of their whereabouts.

The Manitoba Court of Appeal case of R. v. J.T.J., Jr. ${ }^{57}$ and the British Columbia Court of Appeal case of $R$. v. Dixon ${ }^{58}$ seemingly are based, in part, on the same reasoning. An important case in this regard is the Alberta Court of Appeal decision in $R$. v. Greffe.$^{39}$ In this case the Respondent was tried and acquitted on counts of importing heroin into Canada and possession of heroin for the purpose of trafficking. Based upon a tip that Greffe, returning to Canada from Amsterdam, was carrying heroin, the R.C.M.P. and of ficers of Canada Customs arrested him upon his arrival at Calgary International Airport. External searches and a strip search revealed nothing. The Respondent was turned over to the R.C.M.P. and was taken to a local hospital. At the hospital he was internally searched by a medical doctor. This search resulted in the recovery, from the rectal cavity, of two condoms containing $\mathbf{4 0}$ grams of heroin. The narcotics had a street value worth approximately $\$ 225,000.00$. The trial Judge acquitted the Respondent because his Charter rights had been infringed during his detention. The infringement of the rights included a violation of section 10(a) - the right to be informed promptly of the reason for arrest; a violation of section 10 (b) - his right to retain and instruct counsel without delay; and a violation of section 8 - his right to be secure against

53. Supra n. 19 at 286.

54. Supra n. 52 at 399.

55. Supra n. 28 and accompanying text.

56. Supra n. 52 at 399.

57. (1988) 50 Man. R. (2d) 300 (Man. C.A.).

58. (1987) 38 C.C.C. (3d) 519 (B.C.C.A.).

59. (1988) 57 Alta. L.R. (2d) 161 (Alta. C.A.). 
unreasonable search and seizure. The trial Judge excluded the evidence and an acquittal followed. Pursuant to section 613(4)(b)(ii) of the Criminal Code, the Court of Appeal set aside the not guilty verdict, entered a conviction for importing a narcotic into Canada, and remitted the matter back to the Court of Queen's Bench for sentencing. During the course of his judgment in this matter, Justice McClung had occasion to make the following statements: ${ }^{60}$

But exclusion only lies when the accused supplies a material fact and it is clear, at least on the civil standard of proof, that the fact would not have emerged had the Charter been observed. . . . Here, neither the delay in telling Greffe the real reason for his arrest (which undermines his right to counsel) nor his hospital search, if it was unreasonable, created the narcotics, the possession of which defined the crime. With due respect, the injunctions of Therens did not demand the rejection of the evidence of Greffe's heroin possession in this case. The real evidence existed irrespective of the violation of the Charter. [Emphasis added]

Near the end of his judgment Justice McClung had occasion to say the following: ${ }^{61}$

As I have indicated, the Charter violations found by the learned trial judge and which were instrumental in the acquittal did not create, or result in, evidence of Greffe's guilt. . . . Beyond that, admission of the evidence that was recovered could not have negatively influenced the adjudicative fairness of Greffe's trial. Greffe's heroin was a fact. It was not the child of a deficient arrest. Nor was there call for the court to disassociate itself from the conduct of the police. [Emphasis added]

The undeniable conclusion, if this line of reasoning continues to be followed, is that all real evidence which pre-existed the violation of the Charter right will be admissible, whereas only evidence which is created from the violation of the right will be excluded. This of course, is not at all what the plain wording of section $24(2)$ states. To reiterate once again, the section uses the phrase "obtained in a manner". This is very different from the phrases "the product of", 62 "created by", ${ }^{63}$ "the child of", 64 or any similar phrase which is the product of judicial revisionism.

\section{Good Faith}

The notion of "good faith" plays an important part in determining whether or not evidence will be excluded pursuant to section $24(2)$ of the Charter. Although, Justice Lamer contended that section 24(2) was not to be used for the purpose of disciplining the police, "good faith" has been an important reason for not excluding evidence. ${ }^{65}$ The first two cases on "good faith" both involved the use of a Writ of Assistance to search and

60. Id. at 167.

61. Id. at 172.

62. Supra n. 44.

63. Supra n. 60 and 61.

64. Supra n. 61.

65. The connection between good faith and the idea of disciplining police is undeniable. If the purpose of exclusion is not to deter or modify behaviour, good faith should not be a factor, for you cannot deter or modify behaviour carried out in good faith. If the only purpose was for the Court to disassociate itself from the action of the police, i.e., to maintain the integrity of the judicial process, that purpose would be present regardless of the existence or nonexistence of good faith. 
seize narcotics. Further, both decisions were delivered on the same day as the Collins decision. In the case of Sieben v. The Queen, Justice Lamer, in commenting on the officer's "good faith", said the following: $: 5$

The only reason that they did not obtain a search warrant is that they believed in good faith that a writ of assistance was sufficient. At that time, the statute authorizing a search under a writ of assistance had not been declared to be inconsistent with the Charter.

Similar statements were made by Justice Lamer in the case of Hamill v. The Queen: ${ }^{67}$

The officers proceeded under a writ of assistance rather than a search warrant because they believed in good faith, that they could rely on the Writ of Assistance, as such writs had not yet been challenged under the Charter.

On the other hand, in Pohoretsky v. The Queen, ${ }^{68}$ the Supreme Court held that when police officers, acting pursuant to the Manitoba Blood Test Act, ${ }^{69}$ secured a blood sample from the defendant while he was unconscious, they were not acting in "good faith". This was in spite of the fact that the Manitoba Blood Test Act had not been previously challenged under the Charter. The conceptual differences between Pohoretsky and Hamill and Sieben are subtle at best. Nonetheless, the officers in Hamill and Sieben are described as having acted in "good faith", while the violation of section $\mathbf{8}$ of the Charter in Pohoretsky is called "wilful and deliberate". Part of the difficulty here may stem from the fact that the term "good faith" has been used to label markedly different scenarios. These scenarios may be characterized in at least four ways:

Scenario \#1: In this scenario the "good faith" arises from the police officer's belief that she has afforded the accused the proper guarantee of his rights. In this case the police officer says to herself: "I am required to afford the accused his right to counsel and to inform him of it and I believe I have done this properly.' An example of this might be the Clarkson case. ${ }^{70}$

Scenario \#2: In this scenario the police officer's belief is based upon established judicial precedent. In this case the police officer says to herself: "If I do such and such, I will have fulfilled the requirements for guaranteeing the accused his Charter rights." An example of this is the Therens case."1

Scenario \#3: In this scenario the police officer's belief is based upon some process of the courts. For example, a search warrant which is obtained from a Judge but later on turns out to be defective. Examples of this might be $R$. v. Harris 72 and $R$. v. Moran. ${ }^{73}$

Scenario \#4: In this scenario the police officer's belief is based upon a previously constitutional statute. Examples of this are Hamill, ${ }^{74}$ Sieben ${ }^{75}$ and Pohoretsky.76

66. [1987] 1 S.C.R. 295 at 299.

67. [1987] 1 S.C.R. 301 at 308.

68. [1987] 1 S.C.R. 945.

69. S.M. 1980 , c. 49 , C.C.S.M., c. B-63.

70. Supra n. 20.

71. Id.

72. (1987) 35 C.C.C. (3d) 1 (Ont. C.A.).

73. (1987) 36 C.C.C. (3d) 225 (Ont. C.A.).

74. Supra n. 67.

75. Supra n. 66 .

76. Supra n. 68. 
These four scenarios are not equivalents. I would argue that situations such as those envisioned by Scenario \#4 provide a greater basis for a claim of "good faith" (Pohoretsky notwithstanding) than do the other three scenarios. Similarly, situations, as described in Scenario \#3, provide a better basis for a claim of "good faith" than do those in Scenarios \#2 and \#1. At the bottom of the ladder, so to speak, are those situations included in Scenario \#1. All we are really saying when we characterize a police officer's behavior as being in "good faith" in these instances is that the police officer has not acted deliberately or maliciously in violating an accused's Charter rights. It should be remembered, however, that the Charter is an effects oriented document and the effect on an individual from even a "good faith" violation of his guaranteed rights is serious. In conclusion, the Supreme Court must urgently take up the task of defining the parameters of "good faith" as it applies in these various situations.

One further point bears mentioning. Of late, there seems to be some focusing on the "good faith" or "bad faith" of the victim of the violation. In The Queen v. Tremblay, ${ }^{n}$ the Supreme Court of Canada allowed the admission of evidence obtained in violation of an accused's right to counsel on the basis that the police officer's hastiness to proceed was provoked by the accused's behavior. From the moment the accused was stopped on the road to the moment he was asked to provide a sample of his breath, his behavior was characterized as "violent, vulgar and obnoxious". The trial Judge found as a matter of fact that the accused was "deliberately attempting to make the investigation difficult" and "was actively obstructing it". In upholding the admission of the evidence, Justice Lamer stated: ${ }^{78}$

Generally speaking, if a detainee is not being reasonably diligent in the exercise of his rights, the correlative duties set out in this Court's decision in $R$. v. Manninen ... imposed on the police in the situation where the detainee has requested the assistance of counsel are suspended and are not $\mathrm{a}$ bar to their continuing their investigation and calling upon him to give a sample of his breath. While this is not the case here, the accused's conduct was, to some degree, misleading in that regard. While the police's hastiness does not change the fact that the detainee's right to counsel was violated, the reasons therefore make it understandable and are relevant when one addresses the s. 24(2) issue. In my view the admission of evidence obtained would not, having regard to all the circumstances, bring the administration of justice into disrepute.

This decision seems to have prompted, at least in part, Justice McClung's decision in the Greffe ${ }^{79}$ case. In that case, in attempting to refute the characterization by Justice Harradence of the police activity as being the epitome of "bad faith, deliberate, flagrant, and serious", Justice McClung stated: ${ }^{80}$

The false information, equated by the trial judge to a breach of s. 10(a), was not so serious that exclusion was demanded. I say so because it is clear from the record that the misinformation from the R.C.M.P., amounting to a Charter breach, pales when compared to Greffe's own duplicity in attempting to gain entry into Canada, posing as a routine traveller.

77. [1987] 2 S.C.R. 435 .

78. Id. at 439.

79. Supra n. 59.

80. Id. at 168. 
Further, in discussing the rectal search, and thus the scope of the intrusion upon Greffe, Justice McClung continued as follows: ${ }^{81}$

\begin{abstract}
One should not forget that the burying of the drugs within Greffe's, the citizen's, bodily cavity was the free election of Greffe, the heroin courier. His motives are easily inferable. Firstly, to avoid detection under a routine exterior search, secondly to discourage the possibility of an internal search simply because of its repellent nature and thirdly, if the narcotics were recovered to introduce the defence which prevailed at his trial - the violation by the state of a citizen's right to continuing bodily integrity. With these advantages in mind, Greffe was the first to profane his own bodily integrity. In doing so, he chanced the medical intrusion which followed and in my view defined its scope.
\end{abstract}

The above quotes from Justice McClung's decision in Greffe, seem to indicate the emergence of a doctrine similar to the principle of equity that: "he who seeks equity must do equity" or, dare one say it, "one must come to equity with clean hands". Surely, the development of such a notion is antithetical to the purpose behind the entire Charter. After all, the Charter is an anti-majoritarian document. Its main purpose is to protect those individuals who are not held in any great fondness by society. It is to protect the individual whom society abhors. Even though we may abhor Mr. Greffe's enterprise in trafficking in heroin, he is still entitled to the protections of the Charter.

\title{
V. CONCLUSION: THE STRUGGLE FOR DUE PROCESS VALUES CONTINUES
}

What conclusions can we draw from the above noted cases? Are any trends discernible? In his treatise, The Limits of the Criminal Sanction, Herbert L. Packer ${ }^{82}$ presents two paradigms of the criminal justice system: the "crime control" and "due process" models. ${ }^{83}$ Although they share certain assumptions, the two models are polar opposites in terms of the nature of the criminal process they represent. Indeed, each is an abstraction of a separate value system which defines the polarities. Consequently, neither paradigm represents reality. Rather, each is an ideal vying for attention when decisions are made affecting the nature of our criminal justice system.

The Crime Control Model values the repression of criminal conduct as the most important function of the criminal justice system. Efficient apprehension and conviction of criminals is paramount. A premium is placed on speed and finality. Speed requires informality and uniformity of procedures. Finality, requires the minimization of possible challenges to the methods employed for the apprehension and conviction of criminals. Consequently, extra-curial processes are to be preferred to judicial ones. At the heart of the model lies the "presumption of guilt", a factual and descriptive assumption of the probability of guilt or innocence in any given case.

Central to the Due Process Model is a healthy skepticism for the reliability of the criminal justice process. There is an insistence upon

81. Id. at 171 .

82. H.L. Packer, The Limits of the Criminal Sanction, Stanford (1968).

83. The description of models which follows is taken from Ziff and Elman, supra n. 40. 
formal adjudicative processes. The adversary system of adjudication is a result of an attempt to guard against the possibility of error in the system. An integral feature of this model is "the presumption of innocence". The "presumption of innocence" is a normative and legal notion. It requires procedural due process and results in rules protecting the accused. In order to ensure that the rules established for the protection of the accused are honored, the criminal process must be seen as an appropriate forum for correcting its own abuses.

In this way, meaningful pressure can be applied to police agencies to conform to rules established to protect the accused. It is the limitation of state power which is at the heart of the Due Process Model. ${ }^{84}$

Although Packer's approach has been called trite, it is a useful mechanism for the examination of the criminal justice system. In particular, the struggle between the two paradigms provides an interesting analogy to the balancing process which must take place in litigation involving the Canadian Charter of Rights and Freedoms. Indeed section 24(2) can be seen as the stage upon which the two models vie for attention and supremacy. The recent developments in the areas of causation and "good faith" represent a marked movement away from due process values in favor of the Crime Control Model.

If any case epitomized the crime control model it was $R$. v. Wray. In that case, pride of place was given to those concerns related to the apprehension and conviction of criminal actors. Far less consideration was given to due process values. Indeed, due process concerns were of only marginal interest to the Court.

Section 24(2) was designed to correct the imbalance between crime control and due process values which was created by the Supreme Court's decision in Wray. As was noted earlier, the present section 24(2) was a direct result of criticisms which were levelled at the Wray judgment. This was reaffirmed by Justice Cory in $R$. v. Woolley when he stated:8s

The rule enunciated by the Supreme Court of Canada in Wray has, of course, been abrogated by s. 24(2) of the Charter ...

In spite of this, the cases discussed in this comment indicate a return to values implicit in Wray, if not to the theory of Wray. Indeed $R$. v. Woolley, $R$. v. Dixon, ${ }^{86}$ and $R$. v. J.T.J., Jr. ${ }^{87}$ are examples of cases where no different decision was rendered than would have been given under the Wray doctrine. The cases discussed in this comment indicate that some courts, at least in criminal law matters, are attempting to restrict the effectiveness of the Charter.

Civil libertarians struggled to ensure that the Canadian Charter of Rights and Freedoms contained a workable remedies provision. This is undeniable from the history. The Collins case represents an important decision on the balancing of crime control and due process values. Recent developments in the areas of causation and "good faith" indicate the need for those people who are concerned with the rights of individuals to continue their struggle to ensure that due process values are not ignored in the pursuit of efficient law enforcement.

84. Supra n. 82 at $165-166$.

85. Supra n. 52 at 396.

86. Supra n. 58.

87. Supra n. 57. 